\title{
熱傷治療中に生じた遅発性溶血性輸血副作用によりD--血液 型が判明した一例
}

\author{
山田 尚弘*1 辻本 雄太*1 松村 宣寿*1 門馬 法子*1 \\ 奥山 広也 $* 1$ 加藤 美加 $* 2$ 森野 一真 $* 1$ \\ ${ }^{* 1}$ 山形県立中央病院救急科, $* 2$ 同 輸血部 ( ₹ 990-2292 山形県山形市大字青柳 1800)
}

Key words: (1) D--, (2) delayed hemolytic transfusion reaction (DHTR), (3) irregular antibody

\section{背 景}

D-- 血液型 (以下, D--型) は, Rhの D抗原以外の抗原 (C, c, E, e ) が久損し, 日本人での頻度は約 20 万人に 一人と希少で，高頻度抗原 Rh17 (Hr0) に対する抗体検 出で判明することが多い。今回, 熱傷植皮術に伴う輸 血による遅発性溶血性輸血副作用 (delayed hemolytic transfusion reaction, DHTR) を契機にD--型が判明し た症例を経験した。本例は, 受傷後3回の不規則抗体 検査がすべて陰性で，4回目に初めて陽性となり，D-型が判明したため, DHTRの回避が困難であった。

\section{症 例}

患者 : 80 歳, 女性, 3 妊 3 産, $\mathrm{O}$ 型 $\mathrm{Rh}(+)$ 。

既往歴：リウマチ性多発筋痛症。

内服薬：プレドニゾロン $5 \mathrm{mg} / \mathrm{day} 。$

輸血歴：なし, 術前不規則抗体検査は陰性。

現病歴：仏壇の蛹燭の火が衣類に燃え移り，顔面と 頸部，前胸部に深達性 II 度熱傷および III 度熱傷と，気 道熱傷を受傷した。熱傷面積 $12 \%$, burn index 7 で, 受傷から 15 日目にデブリードマンおよび分層植皮術 を行ったところ, 術中に Hb $6.5 \mathrm{~g} / \mathrm{dL}$ と低下したため, $\mathrm{O}$ 型 $\mathrm{Rh}(+)$ 赤血球液-LR (red blood cells-leukocytes reduced, RBC-LR) を4単位輸血した。その後も貧血 が進行し，受傷 22 日目にRBC-LRを 4 単位輸血した。
受傷 34 日目に血色素尿が出現。4 41 日目にはHb 6.4 g/dL, BUN $61.0 \mathrm{mg} / \mathrm{dL}, \mathrm{Cr} 2.31 \mathrm{mg} / \mathrm{dL}$, LDH 419 $\mathrm{U} / \mathrm{L}$ とDHが上昇しており, 腎障害と貧血が増悪し た。上部消化管内視鏡検査などで出血源は不明。 42 日目と 43 日目にRBC-LRを 2 単位ずつ輸血。その後も 57 日目にはHb $7.2 \mathrm{~g} / \mathrm{dL}$, BUN $68.4 \mathrm{mg} / \mathrm{dL}, \mathrm{Cr} 4.89$ mg/dL, LDH 387 U/Lであり腎障害と貧血, LDH高 值は改善しなかった。受傷から 43 日目まで腋窩温 38 度台の発熱があり, リウマチ性多発筋痛症の影響を考 え, 受傷日より中断していたステロイド投与を, 44 日 目よりプレドニゾロン $20 \mathrm{mg} / \mathrm{day}$ で増量して再開し たところ，その後解熱を認めた。58日目の不規則抗体 検査で初めて陽性となり, 同日の輸血前血液検体を日 本赤十字社 (以下, 日赤) 東北ブロック血液センターで 抗体検查し, 抗Rh17 (Hr0) 抗体, 抗E抗体, 抗e抗体 を認め, D--型と診断された。その後, 適合赤血球輸血 と輸液により，貧血と腎障害は改善した (Fig. 1)。

\section{考 察}

D--型はRHCE遺伝子の欠損により Rh因子の主要抗 原のうち $\mathrm{D}$ 抗原以外の抗原が発現しない血液型で, 日 本人における割合は約 20 万人に一人とされる1)。Rh型 では陽性と判定され，不規則抗体検出率も約 1 ～2\% 2) と低いことから見逃されやすい。D--型で発現するRh 抗原はD, G, Rh29のみで, 輸血や妊娠を契機に,

\footnotetext{
A case of delayed hemolytic transfusion reaction found to be the D-- phenotype during burn treatment

Takahiro Yamada*1, Yuta Tsujimoto*1, Nobutoshi Matsumura*1, Noriko Monma*1, Hiroya Okuyama*1, Mika Kato*2, Kazuma Morino*1

* ${ }^{1}$ Department of Emergency Medicine, *2 Blood Transfusion Department, Yamagata Prefectural Central Hospital (1800 Aoyagi, Yamagata, Yamagata 990-2292, Japan)
} 


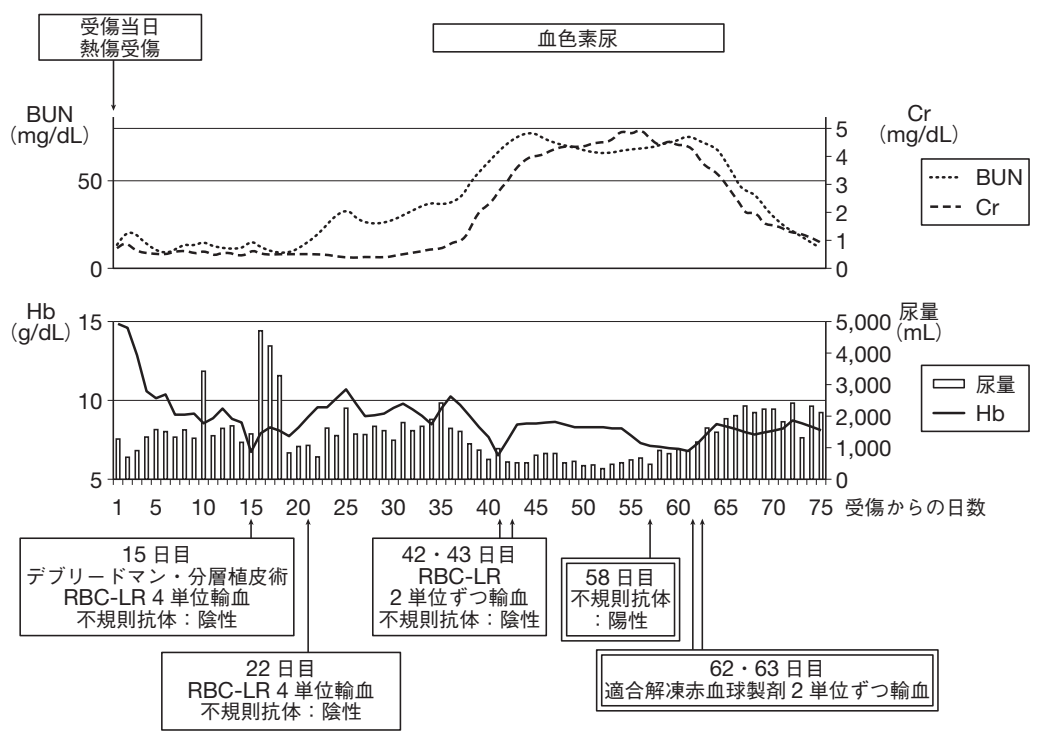

Fig. 1 腎機能と $\mathrm{Hb}$ の推移

適合赤血球製剤が輸血されるまで，DHTRによる腎障害と貧血が進行した。

DHTR, delayed hemolytic transfusion reaction; RBC-LR, red blood cells-leukocytes reduced.

D--型では発現していない高頻度抗原 Rh17 (Hr0)に対 して産生される, 抗Rh17 (Hr0) 抗体の検出により判 明することが多い3)。

日赤血液センターでは, D--型を最も頻度の低い血 液型であるI 群に分類しており，供血者が限られるた め, 供血を凍結製剤として保存している。

本例の血色素尿，腎障害と貧血の進行などは，抗Rh 17 (Hr0) 抗体, 抗E抗体, 抗e抗体によるDHTRと考 える。DHTRは輸血による抗原刺激により産生また は増加した抗体が輸血赤血球と反応し, 24 時間以降に 溶血に伴う症状が出現する反応で, 多くは妊娠や輸血 などの前感作に対する二次免疫応答である。検出限界 以下の抗体でも溶血反応が生じることがあり,未然に 防ぐことは難しい4) 6)。本例は血色素尿が出現後 42 日目の不規則抗体検査では陰性であり, 58 日目の血液 検体で初めて陽性となった。当院での不規則抗体検査 は低イオン強度溶液間接抗グロブリン法とポリエチレ ングリコール間接抗グロブリン法を用いており，現時 点でこれ以上検出感度を上げることは難しく, 事前に 察知して回避することや, 血色素尿の出現がDHTRに よるものと判断することは困難であった。本例は, 受 傷日より中断していたステロイド投与を，44日目から 再開したことで, DHTRの病勢がステロイド投与前に 比較して抑えられたと考えるが, DHTRは死亡例も報 告されるため7), 注意を要する。

\section{結 論}

今回, 熱傷治療中の DHTRを契機にD--型が判明し
た症例を経験した。事前検査で適合したとしても溶血 性輸血副作用を生じ，なおかつ血色素尿が出現した後 の不規則抗体検査でも陰性となる場合があるため, 十 分な注意と観察が必要である。

本報告にあたり，患者から書面で同意を得た。

本論文の全著者に規定されたCOIはない。

\section{文 献}

1) 岡村郁恵, 小倉和外, 池田宇次. 稀少な D--血液型の急性骨 髄性白血病に対する血縁者間末梢血幹細胞移植. 日造血細 胞移植会誌 2014;3:93-6.

2) Takeshita A, Watanabe H, Fijihara H, et al. Collaborative study of irregular erythrocyte antibodies in Japan: results from the Japanese study group of allo-immunity and antigen diversity in Asian populations. Transfus Apher Sci 2010;43:3-8.

3) 内川 誠. 第吕章-A-3. Rh $(\mathrm{RH})$ 血液型, Rh-associated glycoprotein(RHAG) 血液型 7.Rh 血液型抗原と変異型. 輸 血学改定第4版. 東京 : 中外医学社 ; 2018. p. 240-2.

4) 石丸 健, 佐藤進一郎, 藤井康彦. 遅発性溶血性輸血副作用. 輸血副反応ガイド。東京：日本輸血・細胞治療学会; 2014. p.37-40

5) 川畑絹代, 大戸 斉, 前田平生, 他. 第 $\mathrm{V}$ 章- $\mathrm{A}$. 溶血性輸 血反応. 輸血学改訂第 4 版. 東京 : 中外医学社 ; 2018. p. 616-59.

6) 阿波屋典子, 井上昌子, 虫明佳子, 他. 遅発性溶血反応を 起こした-D-/-D-型の1例。日輸血会誌 1987;33:755-60.

7) Hillman NM. Fatal delayed hemolytic transfusion reaction due to anti-c+E. Transfusion 1979;19:548-51. 